Mr Vlado N. Radić, major, dipl. inž.

\section{PRIMENA OBRADE MATERIJALA EKSPLOZIJOM U INDUSTRIJI}

U mnogim granama industrije neprekidno se povećava potreba za materijalima koji objedinjavaju visoka mehanička svojstva sa, na primer, povećanom otpornošću u agresivnim sredinama. Najprihvatljiviji za rad $\mathbf{u}$ takvim uslovima su višeslojni ili kompozitni materijali sa osnovom od jeftinih konstrukcionih člika, a sloj (ili slojevi) koji je u kontaktu sa agresivnom sredinom, izrađen je od visokolegiranog čelika, legura ili obojenih metala. Za dobijanje bimetalnih ili višeslojnih materijala u praksi se već dugo primenjuje zavarivanje eksplozijom. To je proces u kome se eksploziv koristi za generisanje visokog pritiska kratkovremenog dejstva, pri čemu se metalne ploče dovode u direktan kontakt i zavaruju delovanjem međuatomskih sila rešetke. Tako formiran bimetal poseduje izuzetna termomehanička svojstva i pogodan je za dalje klasične postupke prerade, obrade i zavarivanja.

\section{Uvod}

Obrada materijala eksplozijom datira od početka četrdesetih godina. U SSSR-u ona je započeta radovima na ispitivanju mehanizma protivoklopnih kumulativnih punjenja, koje je izvodila grupa istraživača u Kijevu pod rukovodstvom akademika Lavrentijeva. Uporedo sa razradom hidrodinamičke teorije kumulacije, otkriveno je zavarivanje eksplozijom $u$ nekoliko oblika - šema, čije su kasnije modifikacije dobile široku primenu [1]

Polovinom četrdesetih godina započeti su radovi sa eksplozivnim oblikovanjem kojima je rukovodio prof. Pihtovnikov. Sredinom pedesetih godina prof. Rjabinin u Institutu hemijske fizike u Moskvi, počeo je ispitivanje sabijanja praškastih materijala eksplozijom, radi ostvarenja sinteze dijamanta eksplozijom [2].

Radovi na ojačavanju čelika sa povećanim sadržajem mangana pomoću eksplozije započeti su 1960. godine u Novosibirsku [1]. Na istom mestu, posle dužeg zastoja, nastavljena su ispitivanja zavarivanja eksplozijom (započeta 1961. godine), a sredinom šezdesetih godina sistematska ispitivanja proširena su na presovanje prahova eksplozijom. $U$ to vreme počela su prva ispitivanja čvrstoće detonacionih komora, koja su omogućila da u kratkom roku počnu praktično da se koriste (u laboratorijama i na poligonima) za izvođenje procesa obrade metala eksplozijom.

Danas se obrada materijala eksplozijom izvodi u nizu naučno-istraživačkih ustanova, laboratorija, proizvodnih pogona, kako u zemljama bivšeg SSSR-a, tako i u zapadnim zemljama, prvenstveno u SAD, Francuskoj i Japanu. Organizovana je potpuno različita primena tih procesa $u$ različitim granama industrije i mašinogradnje.

Tehnologija obrade materijala eksplozijom primenjuje se $u$ : mašinskoj 
industriji, brodogradnji, petrohemijskoj $\mathrm{i}$ hemijskoj industriji, prehrambenoj industriji, građevinarstvu, elektroindustriji.

\section{Ojačavanje čelika eksplozijom}

Ojačavanje čelika sa povećanim sadržajem mangana $(>12 \%)$ patentirano je 1951. godine u SAD. U većini radova za ojačavanje se koriste kontaktna eksplozivna punjenja od plastičnih eksploziva čija je brzina detonacije $\mathrm{D}=7000$ do $8000 \mathrm{~m} / \mathrm{s}$, a gustina $\rho=1,5 \mathrm{~g} / \mathrm{cm}^{3}$. Pri tome, pritisak na frontu detonacionog talasa dostiže oko $20 \mathrm{GPa}$, a u zavisnosti od načina iniciranja detonacije, $u$ delu koji se ojačava, generiše se udarni talas (UT) sa pritiskom na frontu od 20 do $40 \mathrm{GPa}$. Prostiranje udarnog talasa po metalu izaziva povećanje tvrdoće, granice kidanja i tečenja, ali i smanjenje udarne viskoznosti i plastičnosti. U tabeli 1 navedena je promena mehaničkih svojstava čelika sa povećanim sadržajem mangana pri različitim šemama ojačavanja prikazanim na slici 1.
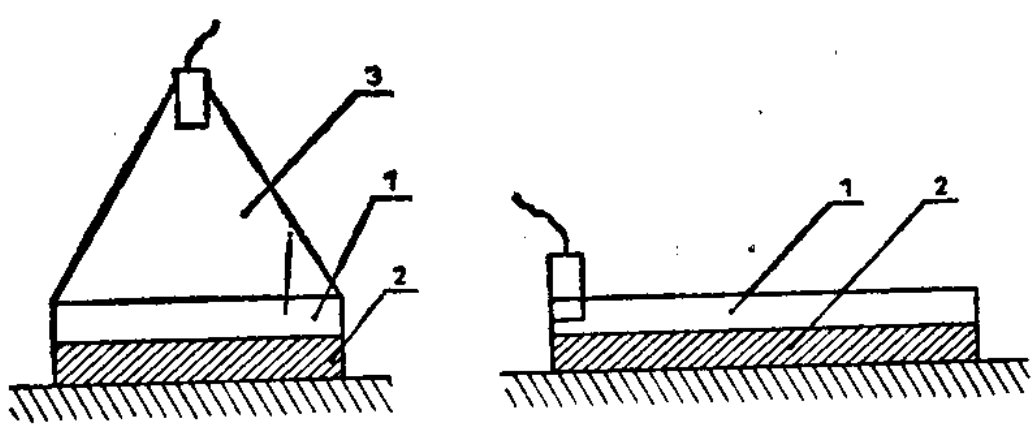

Sl. 1 - Seme ojačavanja eksplozijom 1 - eksplozivno punjenje, 2 - metal koji se ojačava, 3 - generator ravnog talasa.

Pri ojačavanju delova složenih oblika potrebno je izvršiti pravilan izbor geometrijskog rasporeda eksplozivnog punjenja, tako da se obezbedi ravnomerno opterećenje detonacionim talasom površine koja se ojačava.

Korišćenje snažnih plastičnih eksploziva, za ostvarivanje efekata oja-
Promena mehaničkih svojstava čelika sa povećanim sadržajem mangana pri različitim šemama ojačavanja

\begin{tabular}{|l|c|c|c|c|c|}
\hline $\begin{array}{c}\text { Stanje } \\
\text { materi- } \\
\text { jala }\end{array}$ & $\begin{array}{c}\sigma_{\mathrm{m}} \\
(\mathrm{MPa})\end{array}$ & $\begin{array}{c}\sigma_{0.2} \\
(\mathrm{MPa})\end{array}$ & $\begin{array}{c}\delta \\
(\%)\end{array}$ & $\begin{array}{c}\Psi \\
(\%)\end{array}$ & $\mathrm{HV}$ \\
\hline Početno & 875 & 435 & 36 & 33 & 200 \\
\hline $20 \mathrm{GPa}$ & 1025 & 730 & 31 & 28 & 390 \\
\hline ETO $^{*}$ & 975 & 475 & 46 & 31 & 240 \\
\hline
\end{tabular}

* ETO - eksplozivnotermička obrada

$\left(20 \mathrm{GPa}+\right.$ kaljenje na $1050^{\circ} \mathrm{C} \mathrm{u}$ vodi).

čavanja, nije uvek povoljno iz ekonomskih razloga. U poslednje vreme realizovana je ideja o korišćenju međusloja od poroznog materijala između eksploziva i površine koja se ojačava. Ako se, pri prostiranju detonacije eksplozivnog punjenja, $u$ poroznom materijalu realizuje mahovska konfiguracija UT, pruža se mogućnost korišćenja jeftinijih niskoimpulsnih eksploziva za ojačavanje [3] - slika 2.

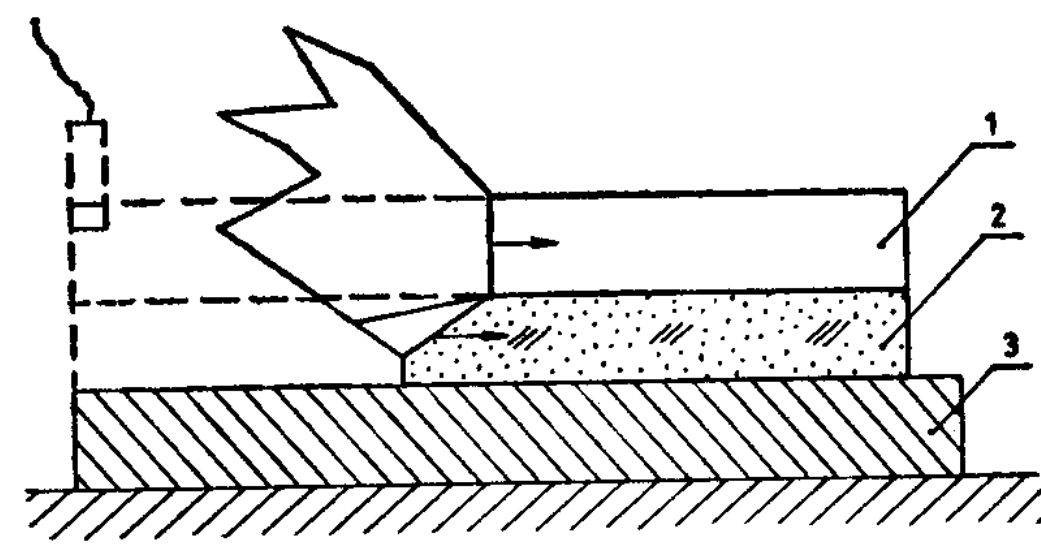

St. 2 - Ojačavanje eksplozijom sa međuslojem

1 - eksplozivno punjenje, $2-$ međusloj, 3 - metal koji se ojačava.

\section{Eksplozivnotermička obrada (ETO)}

Početkom sedamdesetih godina $u$ tehnologiji ojačavanja metala eksplozijom predložene su bitne dopune. Pri- 
kaz prvih ispitivanja isvršenih $\mathrm{u}$ tom pravcu dat je u radovima Deribasa. Kao što je već navedeno, dejstvo UT izaziva povećanje čvrstoće i smanjenje plastičnosti. Do promena mehaničkih svojstava dolazi zbog zasićenosti zapremine materijala koji se određuje defektima kristalne strukture. $\mathrm{Da}$ bi se izbeglo smanjenje plastičnosti, posle dejstva UT, predloženo je da se materijal podvrgne specijalnoj termičkoj obradi kako bi se dobila sitnozrnasta struktura, pošto defekti moraju postati embrioni novih zrna i obezbediti povećanje plastičnosti i udarne viskoznosti pri niskim temperaturama. Za čelike sa povećanim sadržajem mangana, pokazano je da se pri takvoj termičkoj obradi javlja rekristalizaciono žarenje na temperaturi od $1045^{\circ} \mathrm{C}$. Očigledno je da ETO omogućava optimizaciju mehaničkih svojstava čelika sa povećanim sadržajem mangana i ostvarenje znatno boljih eksploatacionih svojstava obrađenih delova.

\section{Konkretna primena ojačavanja}

Od široko primenjenih ojačavanja najviše je razrađena tehnologija ojačavanja jezgara železničkih skretnica. $\mathrm{Na}$ slici 3 prikazana je šema ojačavanja jedne vrste skretnica. U ovom slučaju istovremeno se iniciraju tri eksplozivna punjenja, razmeštena na površinama koje su izložene maksimalnom habanju u toku eksploatacionih opterećenja zbog "preskakanja" točkova sa jedne površine na drugu, usled čega nastaje udarno-abraziono habanje. U početku eksploatacije dolazi do plastičnog sabijanja, koje izaziva smanjenje visine površine kotrljanja (valjanja). Nakon toga ostvaruje se ojačavanje površine kotrljanja (valjanja), pa osnovni doprinos habanju daju abrazivni procesi. Ojačavanje eksplozijom omogućava da se eliminiše početna zona sabijanja i na taj način period upotrebe poveća za četiri puta. Ov-

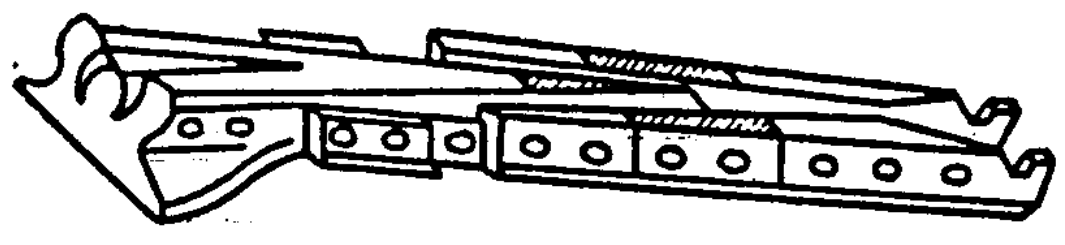

a)

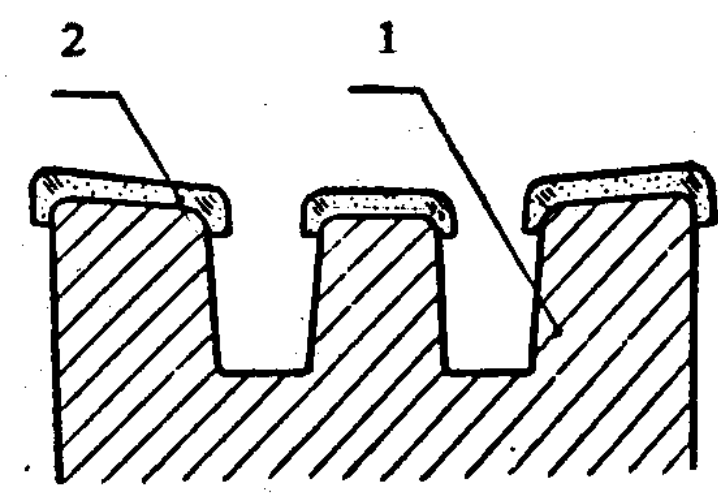

b)

Sl. 3 - Šema ojačavanja eksplozijom železničkih skretnica

a) - skretnica, b) - šema rasporeda eksplozivnog punjenja

1 - telo skretnice, 2 - eksplozivno punjenje.

de je važno da materijal skretnica bude što kvalitetniji, pa će i efekat ojačavanja biti izraženiji.

Razrađena je i uspešno se koristi tehnologija ojačavanja eksplozijom zubaca bagera različitih vrsta i namena. Sema ojačavanja prikazana je na slici 4.

Taj metod povećanja perioda upotrebe brzohabajućih delova našao je široku primenu u rudarstvu. Ojačavanje eksplozijom omogućava da se period upotrebe zubaca bagera, poveća za 1,5 do 2 puta. Stene u rudnicima imaju različitu tvrdoću, što određuje preovladavanje udarnog ili abrazionog habanja na radnim površinama zubaca pa ostvareni efekat ojačavanja može biti različit.

$\mathrm{Za}$ delove složene geometrijske konfiguracije, kao što su obloge (oplate) drobilica, razrađena je posebna tehnologija ojačavanja. Jedna od šema takvog ojačavanja prikazana je na slici 5 . 


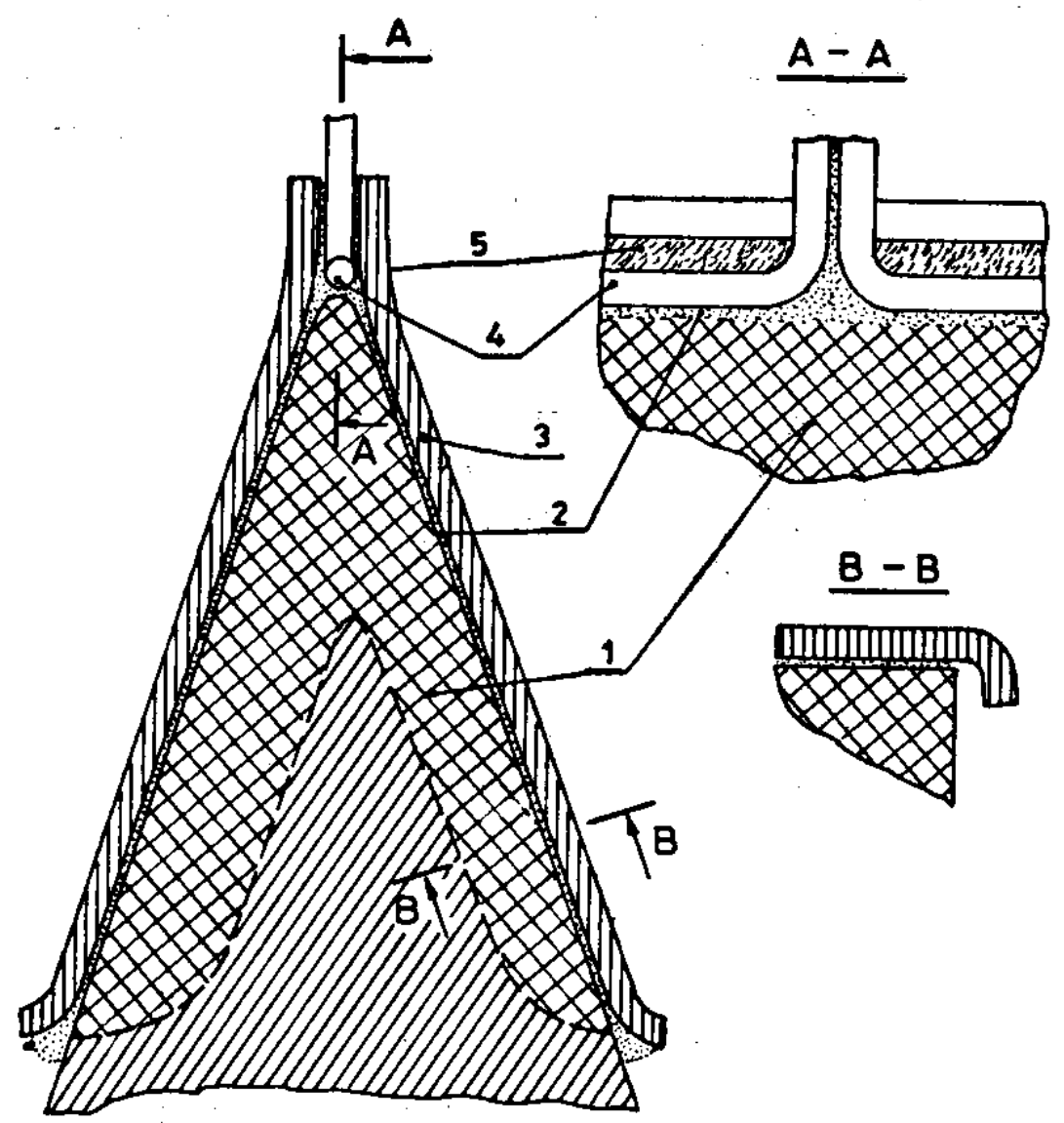

Sl. 4 - Sema ojačavanja eksplozijom zubaca bagera

1 - zona zupca koji se ojačava, 2 - "solidol" (mineralno ulje), 3 - plastični eksploziv, 4 - nasipni heksogen, 5 - detonirajuci štapin.

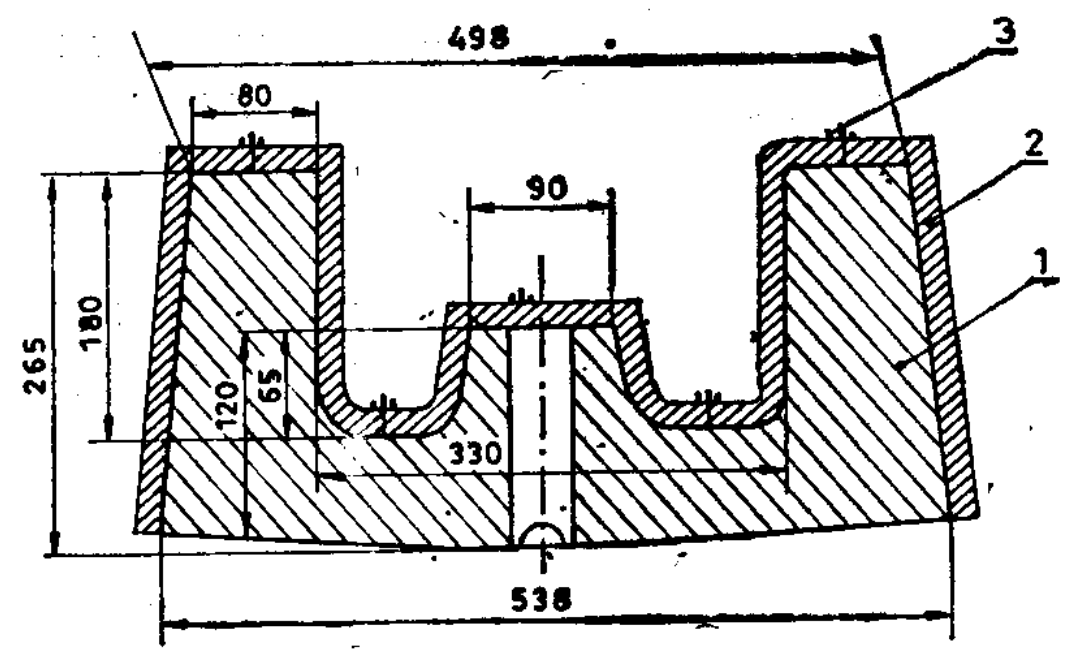

Sl. 5 - Sema ojačavanja eksplozijom obloga drobilica

1 - oplata drobilice, 2 - eksplozivno punjenje, 3 - mesta inicijacije eksploziva.

Pri tako složenoj geometriji radne površine, korišćenje »obuhvatne« šeme razmeštaja eksplozivnog punjenja mora da se izvodi pažljivo, kako bi se izbegle neželjene posledice uzajamnog dejstva međusobno suprotstavljenih elemenata eksplozivnog punjenja, što može prouzrokovati destrukciju delova koji se ojačavaju.

U nizu naučnoistraživačkih ustanova i laboratorija izvode se istraživački radovi u kojima se proučava uticaj dejstva UT na mehanička svojstva različitih metala i legura. Početak tih radova utemeljili su američki autori [4]. Vrlo detaljno su proučeni niskougljenični čelici, kao i disperziono ojačane superlegure na bazi nikla [5]. Za niskougljenične čelike feritne klase proučavana je mogućnost primene ETO radi sniženja praga loma na hladno, pri niskim temperaturama. Dobijeni podaci prikazani su u tabeli 2 .

Ispitivan je efekat ojačavanja nerđajućeg i hemijski postojanog čelika

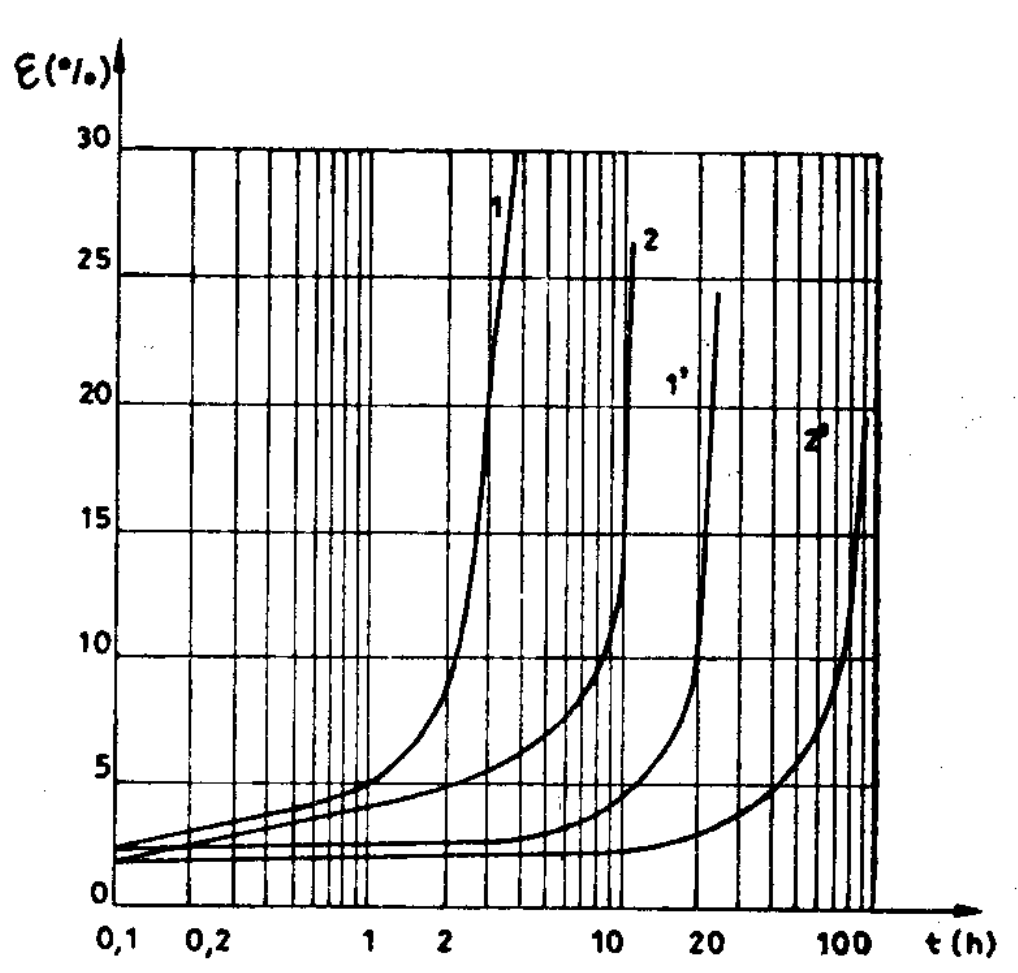

Sl. 6 Krive puzanja superlegura na bazi nikla 1 i 2 - puzanje bez ojačavanja, 1 ' $i$ 2' puzanje posle ojačavanja.

C. 4572 , a rezultati su prikazani u tabeli 3 . Za superlegure na bazi nikla utvrđeno je znatno smanjenje brzine puzanja, što je prikazano na slici 6 . 
Tabela 2

Promena mehaničkih svojstava niskougljeničnih čelika pri ojačavanju eksplozijom

\begin{tabular}{|c|c|c|c|c|c|c|}
\hline \multirow{2}{*}{ Stanje čelika } & \multicolumn{2}{|c|}{$\sigma_{0,2}(\mathrm{MPa})$} & \multicolumn{2}{c|}{$\sigma_{\mathrm{m}}(\mathrm{MPA})$} & \multicolumn{2}{c|}{$\delta(\%)$} \\
\cline { 2 - 6 } & $+20^{\circ} \mathrm{C}$ & $-50^{\circ} \mathrm{C}$ & $+20^{\circ} \mathrm{C}$ & $-50^{\circ} \mathrm{C}$ & $+20^{\circ} \mathrm{C}$ & $-50^{\circ} \mathrm{C}$ \\
\hline Početno & 32,5 & 405 & 540 & 670 & 21 & 19 \\
\hline $\begin{array}{c}5 \mathrm{GPa}+ \\
\text { termička obrada }\end{array}$ & 390 & 570 & 610 & 810 & 19,5 & 13,5 \\
\hline $\begin{array}{c}10 \mathrm{GPa}+ \\
\text { termička obrada }\end{array}$ & 365 & 585 & 565 & 840 & 24 & 22 \\
\hline $\begin{array}{c}\text { Sitnozrnasto } \\
\text { stanje + 10 GPa }\end{array}$ & 473 & 680 & 600 & 865 & 15 & 13 \\
\hline
\end{tabular}

Tabela 3

Promena mehaničkih svojstava nerđajućeg čelika C.4572 pri ojačavanju eksplozijom na sobnoj $i$ povišenim temperaturama

\begin{tabular}{|c|c|c|c|c|c|}
\hline $\begin{array}{c}\text { Pritisak, } \\
\text { GPa }\end{array}$ & $\begin{array}{l}\text { Tempera- } \\
\text { tura } \\
\text { ispitivanja } \\
\left({ }^{\circ} \mathrm{C}\right)\end{array}$ & $\left(\begin{array}{c}\sigma_{\mathrm{m}} \\
\left(\mathrm{daN} / \mathrm{mm}^{2}\right)\end{array}\right.$ & $\left(\begin{array}{c}\sigma_{0,2} \\
\left(\mathrm{daN} / \mathrm{mm}^{2}\right)\end{array}\right.$ & $\delta(\%)$ & $\psi(\%)$ \\
\hline \multirow{4}{*}{$\begin{array}{l}\text { Početno } \\
\text { valjanje }\end{array}$} & 20 & 60 do 70 & 35 do 45 & 40 do 30 & 39 \\
\hline & 600 & 35 do 40 & 20 do 25 & 20 & 10 \\
\hline & 700 & 30 do 33 & 19 do 23 & 16 & 18 do 32 \\
\hline & 800 & 21 do 24 & 15 do 19 & 16 & 20 \\
\hline \multirow{4}{*}{$9 \mathrm{GPa}$} & 20 & 72 & 61 & 35 & 31 \\
\hline & 600 & 40 & 35 & 13 & 39 \\
\hline & 700 & 26 & 23 & 20 & 33 \\
\hline & 800 & 16,2 & 14,6 & 42 & 40 \\
\hline $12 \mathrm{GPa}$ & 20 & 88 & 79 & 20 & 25 \\
\hline $13 \mathrm{GPa}$ & 20 & 88 & 79 & 20 & 30 \\
\hline \multirow{4}{*}{$20 \mathrm{GPa}$} & 20 & 120 & 112 & 10 & 10 \\
\hline & 600 & 48 & 38 & 12 & 12 \\
\hline & 700 & 41 & 35 & 12 & 12 \\
\hline & 800 & 32 & 29 & 5 & 15 \\
\hline \multirow{3}{*}{$40 \mathrm{GPa}$} & 20 & 154 & 144 & 6 & - \\
\hline & 600 & 49 & 43 & 12 & 12 \\
\hline & 800 & 19 & 14 & 50 & 70 \\
\hline \multirow{2}{*}{$5 \underset{\text { tečenja }}{\mathrm{GPa}}+8 \%$} & 20 & 86 & 83 & 4 & 一 \\
\hline & 800 & 28 & 24 & 24 & - \\
\hline
\end{tabular}

NAPOMENA: $12 \mathrm{GPa}$ - kosi udarni talas

$13 \mathrm{GPa}$ - ravan udarni talas 
Fizičko-mehaničke osnove

Najrasprostranjenija šema zavarivanja eksplozijom prikazana je na slici 7.

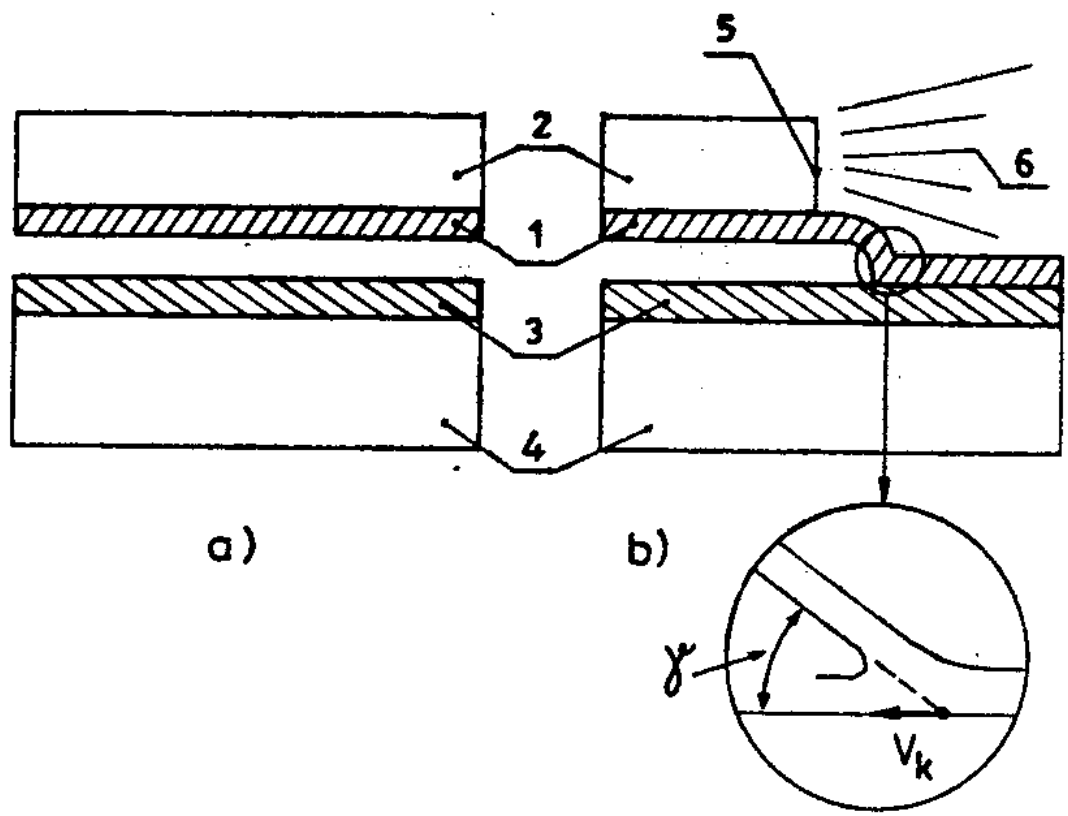

c) procesa zavarivanja eksplozijom

Prema savremenim shvatanjima o zavarivanju eksplozijom postoji donja granica zavarivanja u čijoj se okolini

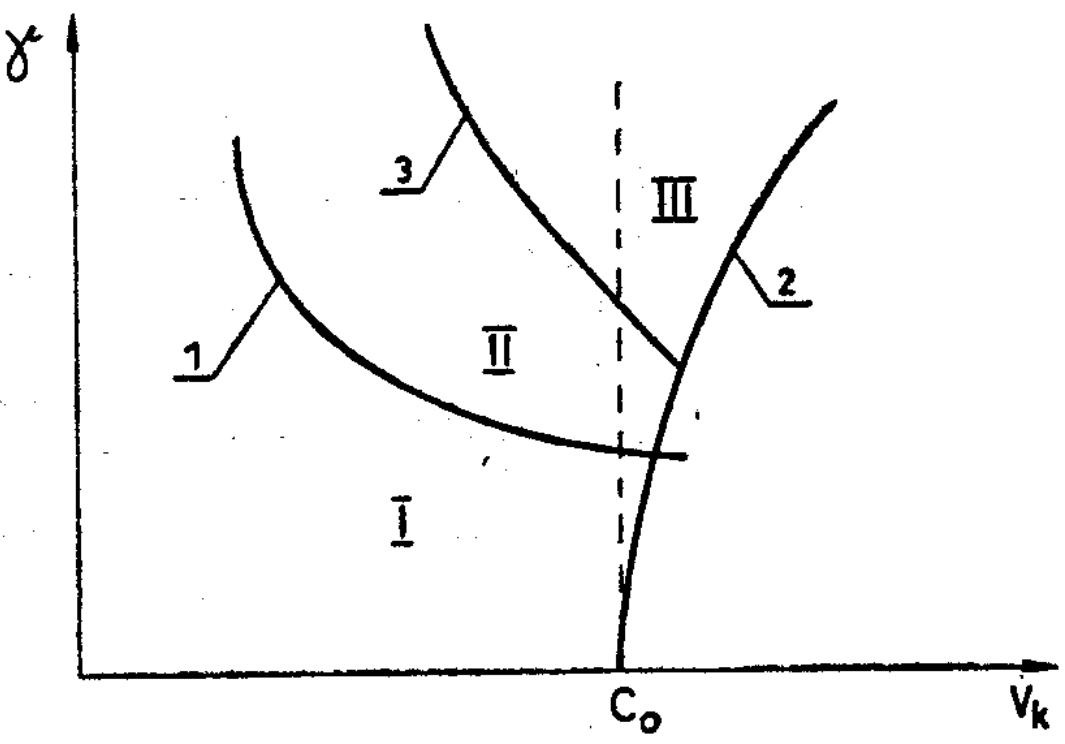

Sl. 8 - Šma oblasti zavarivanja eksplozijom $u$ ravni $\gamma-V_{k}$

1 - donja granica zavarivanja, 2 - granica nadzvučne oblasti, 3 - gornja granica zavarivanja.

Sl. 7 - Sema zavarivanja eksplozijom

1 - ploča koja se ubrzava ilili odbacuje, 2 - eksplozivno punjenje, 3 - nepokretna ploca, 4 - oslonac, 5 - front detonacije, 6 - produkti detonacije.

Ovde su, uporedo sa početnim parametrima - masom eksplozivnog punjenja, zazorom između ploča koji određuje kretanje metalne ploče ubrzane $\mathrm{i} / \mathrm{ili}$ odbačene eksplozijom, uglom pod kojim su postavljene metalne ploče jedna prema drugoj, prikazani osnovni kinematski parametri koji određuju režim sudara dve metalne ploče, a to su brzina tačke kontakta $V_{k}$ i dinamički ugao sudara $\gamma$. Danas se ti parametri eksperimentalno mere sa dovoljnom tačnošću, a povezani su određenim relacijama sa početnịm parametrima šeme zavarivanja.

Ispitivanjima je pokazano da je poznavanje veličina $V_{k}$ i $\gamma$ u prvoj aproksimaciji dovoljno za određivanje oblasti zavarivanja određenog metalnog para, kao što je prikazano na slici 8. ostvaruje najkvalitetnije zavarivanje sa minimalnom količinom rastopa. Struktura zavarenog spoja može biti talasna (slika 9) i bez talasa (slika 10). U oba slučaja čvrstoća spoja prevazilazi čvrstoću slabijeg materijala u spoju. Ukoliko je eksplozija bliže donjoj granici zavarivanja, ekonomski troškovi su najmanji. U prvom redu minimalna je količina eksploziva koja je sposobna da generiše najveće opterećenje na ploču.

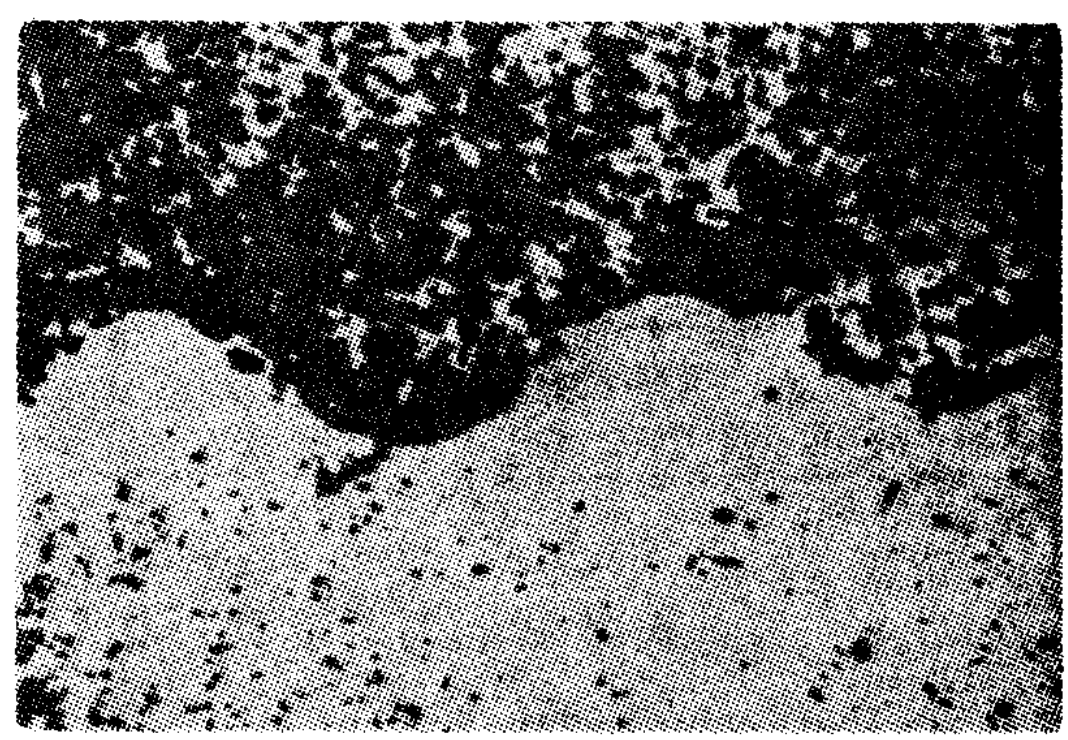

Sl. 9 - Struktura zavarenog spoja sa talasima. 
Veliki broj istraživača bavio se određivanjem položaja donje granice zavarivanja, a najveći doprinos dali su

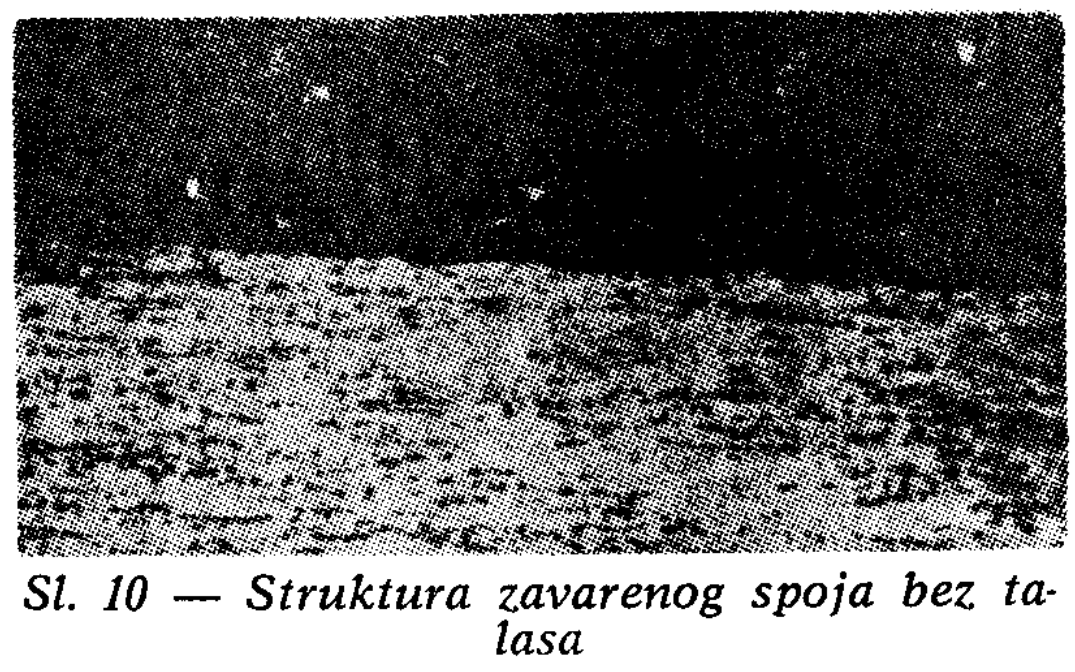

Zaharenko i Simonov [6]. Simonov i Ogolihin otkrili su deo krive koja određuje donju granicu zavarivanja pri većim brzinama tačke kontakta, i predložili hipotezu koja određuje ovu pojavu. Po njihovom mišljenju, pri većim brzinama tačke kontakta, javlja se višak energije koji je prouzrokovan pojavom rastopa i smanjenjem čvrstoće spoja. $U$ radovima Zaharenka predložena je hipoteza koja uslovljava položaj donje granice zavarivanja pojavom toka mase materijala ispred tačke kontakta, određenog procesom sa. močišćenja površina koje se sjedinjavaju. U poslednje vreme Zaharenko i Fomin uspeli su da teoretski odrede položaj donje granice zavarivanja i postignu zadovoljavajuću korelaciju proračuna sa eksperimentalnim podacima niza spojenih metala. Zadaci drugih ispitivanja svode se na otkrivanje osnovnih fizičkih parametara određenih $\mathrm{u}$ toku procesa spajanja $\mathrm{u}$ okolini tačke kontakta, kao što su pritisak, temperatura i drugi, koji su na bilo koji način povezani sa parametrima $V_{k}$ i $\gamma$. Ta ispitivanja omogućiće da se objasne neki još nepoznati činioci koje su otkrili razni autori u procesu istraživanja zavarivanja eksplozijom.

\section{Metalurška ispitivanja}

$\mathrm{U}$ periodu ispitivanja zavarivanja eksplozijom dobijeno je nekoliko stotina spojeva različitih metala i legura. Metalurška ispitivanja zone spoja pokazala su da se ukupna količina dobijenih spojeva može podeliti u dve velike grupe. Klasifikacija je određena prema svojstvima prelaznog (intermedijarnog) sloja koji se prostire duž granice podele, a obrazuje se $u$ toku vremena zavarivanja od nekoliko $\mu \mathrm{s} i$ ima dubinu od nekoliko stotina $\mu \mathrm{m}$. Ispitivanje tog spoja je, zbog njegove vrlo male debljine, vrlo teško i u sadašnje vreme se bazira na ispitivanjima pomoću mikrosondi [1].

U slučaju kada spojeni materijali ne obrazuju hemijsko jedinjenje, u međusloju se primećuje samo koncentracija jednog elementa u drugom, nezavisno od njihove uzajamne rastvorljivosti u običnim uslovima. Spojevi se obrazuju kako pri veoma ograničenoj uzajamnoj rastvorljivosti spojenih materijala (čelik + bakar), tako i pri praktičnom odsustvu rastvorljivosti (bakar + molibden).

U slučaju kada spojeni materijali obrazuju hemijsko jedinjenje, koncentracija elemenata u međusloju približno odgovara spektru mogućih spojeva (gvožđe $+A l$, gvožđe $+\mathrm{Ti}$, itd.). U tom slučaju, kao po pravilu, spajanje metala klasičnim postupcima je teško ukoliko su prelazni hemijski spojevi - intermetalidi krti (lomljivi) i pogoršavaju mehanička svojstva spoja. Pri zavarivanju eksplozijom duž šava vrlo tanak i neravnomeran intermetalni sloj ne pokazuje toliko negativan uticaj na čvrstoću kao kod klasičnih postupaka zavarivanja. U nizu praktičnih slučajeva, npr. za spojeve čelik $+\mathrm{Ti}$ ili čelik + Al, može se postići čvrstoća koja prevazilazi čvrstoću slabijeg metala iz para metala koji se spajaju. Konačno, pri kasnijim termičkim obradama eliminiše se porast intermetala. 
Struktura međusloja pri zavarivanju eksplozijom do sada nije objašnjena. Postojeće pretpostavke o tome da se $u$ tom sloju metal nalazi u amorfnom stanju, zbog nesavršenstva korišćene aparature, ne mogu se smatrati potpuno relevantnim. U sadašnje vreme u literaturi se intenzivno razmatra pitanje da li se zavarivanje eksplozijom ostvaruje $u$ čvrstom ili $u$ tečnom stanju. Treba smatrati nepobitno utvrđenim da proces zavarivanja eksplozijom traje nekoliko $\mu \mathrm{s}$ u toku kojih se metal, u okolini tačke kontakta, nalazi u plastičnom stanju. Tada je metal, ukoliko opterećenje od eksplozije znatno prevazilazi njegovu čvrstoću, sposoban da teče kao tečnost. Očigledno, $u$ toku tog vremena, kristalna rešetka se može sačuvati, premda u vrlo izobličenom stanju koje je slično obliku kristalne rešetke u kumulativnom punjenju. $\mathrm{Na}$ taj način, zavarivanje eksplozijom je prelazna faza između različitih vrsta zavarivanja $u$ čvrstom $i$ tečnom stanju.

Treba naglasiti da višak energije sudara može izazvati topljenje, delimično ili potpuno, površinskih slojeva i da se ostvarena struktura spoja ne razlikuje od zavarivanja $u$ tečnom stanju. Međutim, takvo topljenje, očigledno se javlja kao sekundarni činilac koji ne određuje suštinu pojave. Posebno komplikovan slučaj za ispitivanje nastaje kada se pri optičkom povećanju ne primećuje nikakav međusloj. Najbolje je pretpostaviti da on, pri svemu tome, postoji. Primenom diskretnih metoda merenja i analize radi se na njegovom proučavanju, postepeno se približavajući rastojanjima koja su uporediva sa parametrom rešetke. Ta ispitivanja će dati konačan odgovor na pitanje o prirodi zavarivanja eksplozijom.

\section{Višeslojni materijali}

Sredinom šezdesetih godina $\mathbf{u}$ SSSR-u je osvojena proizvodnja raznih višeslojnih materijala pomoću zavarivanja eksplozijom. Najveći interes predstavlja proizvodnja troslojnih listova od niskougljeničkih čelika (npr. C. 0145, C. 0146 i C. 0147 ) sa obe strane plakiranih nerđajućim čelikom (npr. C..4572) [7]: Pri proizvodnji tog trimetala, ploča od niskougljeničnog čelika debljine $120 \mathrm{~mm}$, dimenzija $4 \mathrm{~m} \mathrm{x} \mathrm{1,2}$ $\mathrm{m}$, posle dve naizmenične eksplozije plakirana je sa obe strane listovima (pločama) od nerđajućeg čelika debljine $15 \mathrm{~mm}$. Dobijeni troslojni materijal obrađuje se valjanjem na deblji. nu 2 do $4 \mathrm{~mm}$, a debljina slojeva nerđajućeg čelika varira u dijapazonu 0,15 do $0,18 \mathrm{~mm}$. Dobijeni materijal koristi se, npr. u poljoprivrednoj mašinogradnji. Antikoroziona otpornost plakiranja u tim uslovima potpuno obezbeđuje potrebna eksploataciona svojstva. U savremenim tehnološkim sistemima mnogih zemalja (SSSR, SAD, Nemačka, Japan, Francuska) osvojena je tehnologija dobijanja bimetala mase do $40 \mathrm{t} i$ površine $16,5 \mathrm{~m}^{2}$. Serijska proizvodnja tog materijala u zemljama bivšeg SSSR-a planirana je $u$ obimu od 15000 tona, u SAD oko 50000 tona, a u Švedskoi i Nemačkoj godišnja proizvodnia kreće se oko 10000 , odnosno 20000 tona.

\section{Izrada kliznih ležajeva primenom zavarivanja eksplozijom}

U mnogim zemljama osvojena je proizvodnja pripremaka za klizne ležajeve, gde se kao osnovni materijal koristi čelik, na koji se eksplozijom nanosi antifrikcioni sloj od mesinga debljine 0,6 do $1,5 \mathrm{~mm}$. Zavarivanje eksplozijom, umesto tradicionalne anodne prevlake, omogućava znatno povećanje produktivnosti rada i za neko- 
liko puta smanjuje utrošak skupocenih i deficitarnih legura bakra. Korišćenje čelika kao osnovnog materijala omogućava da se ostvari povećana čvrstoća ležajeva, a ravnomerna debljina nanesenog sloja mesinga omogućava svođenje mehaničke obrade pri izradi ležajeva na minimum. Osvojena tehnologija dobijanja, kako ravnih, tako i cilindričnih pripremaka, omogućila je dobijanje pripremaka za ležajeve različitih prečnika, od 40 do $300 \mathrm{~mm}$.

Od ostalih antifrikcionih materijala osvojeno je zavarivanje eksplozijom za dobijanje ležajeva koji se koriste $\mathrm{u}$ transportnoj industriji, od bimetala čelik + aluminijum + legura olova. Može se koristiti i kombinovana tehnologija, kada se bimetal, dobijen valjanjem, eksplozijom zavaruje na čeličnu osnovu potrebne debljine.

\section{Presovanje prahova}

Posle pionirskih radova sredinom pedesetih godina, sistematska istraživanja presovanja prahova eksplozijom produžena su do sredine šezdesetih godina. Najintenzivnije je ispitivana šema presovanja u cilindričnom kontejneru, koja je prikazana na slici 11 . Konfiguraciju UT, pri različitim odnosima mase eksplozivnog punjenja i kontejnera, detaljno je razmatrao Staver [5]. Moguće konfiguracije UT prikazane su na slici 12.

Treba napomenuti da se takvi slučajevi primećuju i pri presovanju prahova u ravanskoj geometriji, ali u tom slučaju je komplikovano neutralisati dejstvo talasa rasterećenja, koji teže da razore kontejner. Očigledno, za ravnomernije presovanje praha potrebno je generisati konfiguraciju UT koja ima konusni oblik. Teoretski proračun režima UT zahteva da se koriste izuzetno moćni računari velikih performansi (brzine, memorije), a on je najpotpunije ostvaren $u$ istraživanjima Vilkinsa [8].

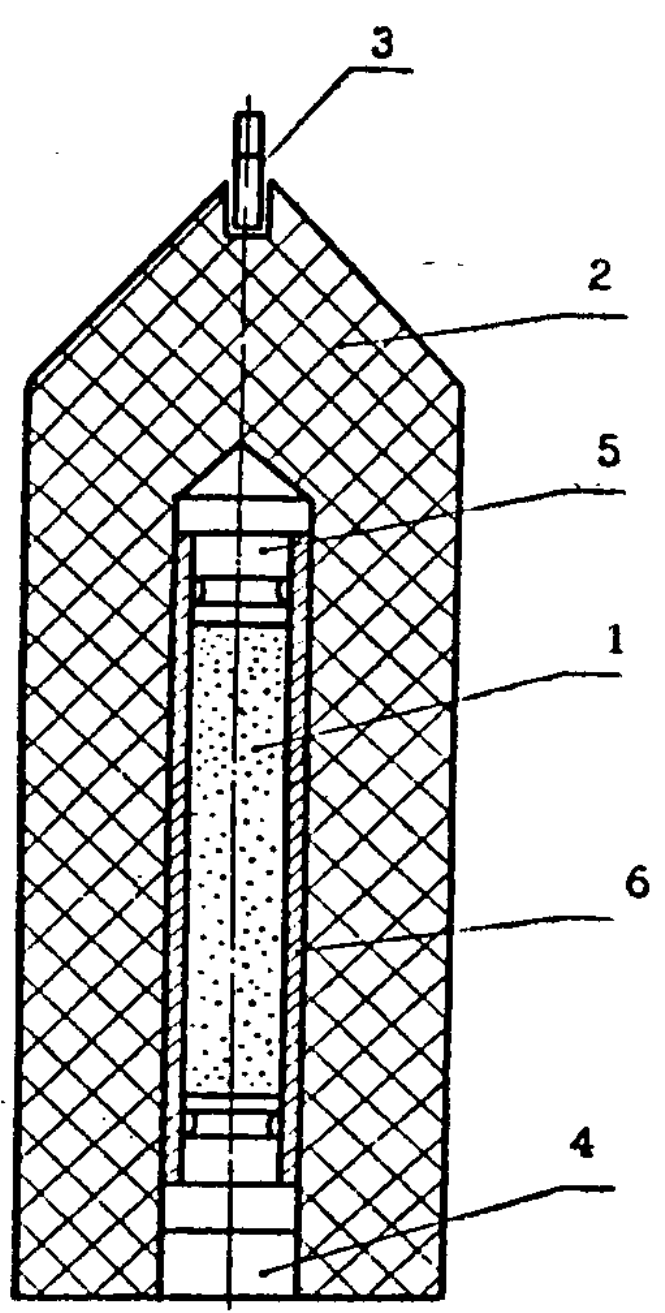

Sl. 11 - Cilindrična šema presovanja eksplozijom

1 - prah koji se presuje, 2 - eksploziv, 3 - elektrodetonator, 4 i $5-$ donji $i$ gornji čep kontejnera, 6 - spoljašnja obloga kon. tejnera.

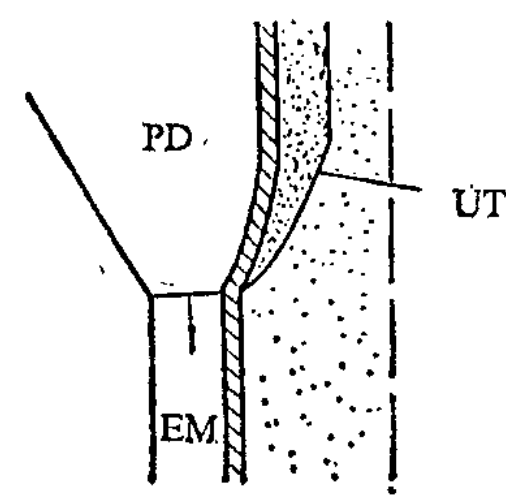

a)

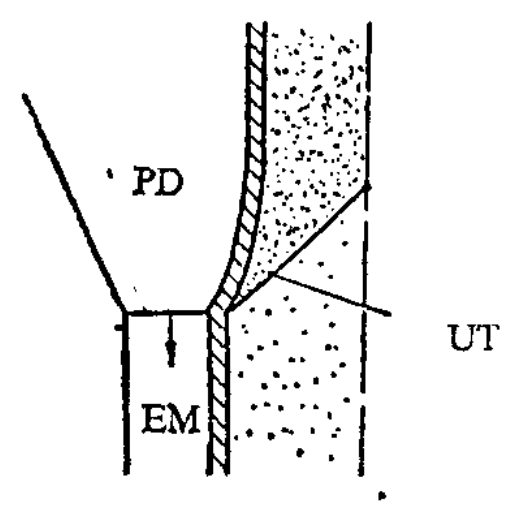

b)

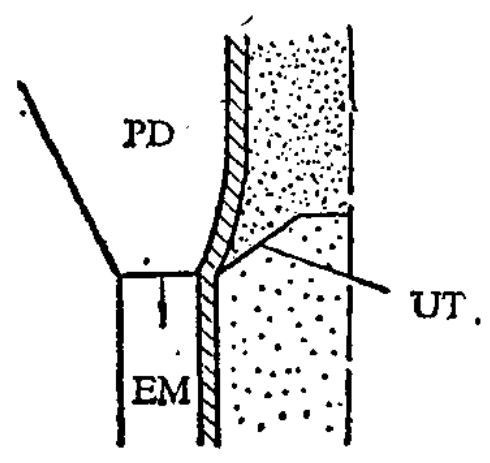

c)

Sl. 12 - Konfiguracije UT pri presovanju poroznih materijala eksplozijom $u$ cilindričnoj geometriji

$P D$ - produkti detonacije, UT - udarni talas, EM - eksplozivna materija. 
Mehanizam spajanja čestica pri presovanju prahova eksplozijom ispitivan je u radovima Stavera, Nesterenka [9] i drugih autora. Osnovni proces koji upravlja obrazovanjem monolitnih struktura i velika plastična deformacija određuje oslobađanje toplote po granicama zrna. Vrlo bitan parametar je karakteristična veličina praha u odnosu na širinu fronta. Pri suviše maloj veličini čestica, oslobađanje toplote iza fronta UT postaje ravnomerno i specifični efekti, koji određuju presovanje prahova eksplozijom, iščezavaju.

Interes za presovanje prahova eksplozijom pobuđen je zbog nekoliko razloga. Među prvima, trebalo je savladati ograničenja zbog kojih zavarivanje eksplozijom ne može biti korišćeno za spajanje krtih nemetalnih materijala, i pokušati spojiti, npr. metal i keramiku. Danas su dobijene, i u proizvodnji se uspešno koriste, kompozicije metal+keramika + metal. Takođe, interes je predstavljalo poboljšanje svojstava nekih materijala. Izvršena je serija ispitivanja sa presovanjem čvrste legure WC (volfram karbid+kobalt), u kojima je pokazano da se ostvaruje ojačavanje kobaltne veze, a utvrđena je i plastična deformacija zrna volfram karbida. Primećeni efekti pružaju mogućnost za pretpostavku da se obradom čvrste legure eksplozijom poboljšavaju eksploataciona svojstva izrađenih delova. Matjicin je ostvario sintezu nekih superprovodljivih materijala $i$ ispitivao njihova svojstva. Deribas i Staver su iz smeše prahova u cilindričnom kontejneru sintetizovali barijum titanat, pri čemu je jednovremeno sa sintezom primećena polarizacija dobijenih kristala.

\section{Amorfni materijali}

U poslednje vreme među istraživačima je izražen interes za probleme obrade eksplozijom amorfnih materijala, takozvanih "metalnih stakala«. Te legure, različitog hemijskog sastava, dobijaju se u laboratorijskim $i$ industrijskim aparaturama u uslovima ekstremno brzog hlađenja iz rastopa, kada u procesu otvrdnjavanja ne uspeva da se formira kristalna rešetka. Materijali imaju unikalna antikoroziona i magnetna svojstva, kao i svojstva čvrstoće, ali specifičnost njihovog nastajanja omogućava da se dobiju samo tanki listovi (folije) ili prahovi, što ograničava mogućnosti realizacije prednosti koje imaju ti materijali. Dobijanje uzoraka klasičnim načinima zavarivanja ili sinterovanja, u principu, niie moguće, ukoliko nastala pregrevanja neizbežno izazivaju stvaranje kristalne strukture. Izvršena ispitivanja obrade "metalnih stakala" pomoću UT generisanih eksplozijom pokazala su da obrada eksplozijom omogućava utvrđivanje amorfnog stanja u obrazovanim monolitnim uzorcima. Taj način pokazao se vrlo perspektivnim za buduću tehničku primenu.

\section{Zaključak}

Kontinuirani tehnološki razvoj i unapređenja koja se ostvaruju u različi. tim granama industrije zahtevaju korišćenje novih ili materijala poboljšanih mehaničkih i drugih svojstava. Sve veću primenu imaju kompozitni materijali, keramike, amorfni i višeslojni materijali, kao i tradicionąlni materijali kojima su radikalno promenjena svojstva. Potreba za materijalima koji objedinjavaju visoka mehanička svojstva sa, na primer, povećanom otpornošću u agresivnim sredinama, neprekidno se povećava. Najprihvatljiviji za rad u takvim uslovima su višeslojni materijali. Kod njih je osnovni (bazni) materijal od jeftinih konstrukcionih čelika, a sloj (ili slojevi) koji je u kontaktu sa agresivnom sredinom, od visokolegiranog čelika, legura ili obojenih metala. 
Za dobijanje bimetalnih ili višeslojnih materijala u praksi se već dugo i sve češće primenjuje zavarivanje eksplozijom. Ovom tehnologijom spajaju se metali koji se drugim tehnologijama ne mogu spojiti ili se to izvodi u vrlo otežanim uslovima. Postupak dobijanja bimetala je izuzetno ekonomičan i brz, a dobijaju se i poboljšane karakteristike termo i elektroprovodljivosti. Ostvaruje se ravnomerna debljina spojenih materijala, a čvrstoća metalne veze osnovnog i plakiranog materijala je veća od čvrstoće manje kvalitetnog materijala $u$ spoju.

Pored operacija spajanja - zavarivanja eksplozijom, sve više se izvode

Literatura:

[1] Deribas, A. A.: Fizika upročnenija i svarki vzrivom, Novosibirsk, Nauka, 1980.

[2] Rjabinin, Ju. N.: Sublimacija kristaliðeskoj rešetki pod dejstvijem siljnoj udarnoj volny, DAN SSSR, 1956, T. 109.

[3] Kostjukov, N. A.: Rolj poristoi prokladki pri obrabotke metallov vzrivom, Trudi II Sovešc. po obrabotki materialov vzrivom, Novosibirsk, 1982 , s. $275-278$.

[4] Response of Metals to High Velocity Deformation, New York, Interscience, 1960.

[5] Deribas, A. A., Staver, A. A.: Udarnoe sžatie poristih cilindričeskih tel, Fizika gorenia i vzriva, 1974, T.10, № 4, s. 568-578.

[6] Zacharenko, I. D.: Calculation of the Lower Boundary of the Explosive Weld Area, 8th Int. Conf. of High Energy Rate Fabrication, San Antonio, 1984.

[7] Konon, Ju. A., Fedorov, V. N., Pervuhin, L. B., Bjikov, A. A.: Korrozionostoikii bimetall dlja seljhozmašinostroenija, Mašinostroenie, 1984 . operacije ojačavanja posebnih elemenata konstrukcije. Ojačavanje ima za cilj da se habanje tih elemenata svede na manju meru, kako bi se što efikasnije produžio period upotrebe. Ojačavanje se izvodi primenom plastičnih eksploziva, zbog promenljive geometrije elemenata koji se ojačavaju. Ukoliko je polazni materijal elemenata koji se ojačavaju kvalitetniji, utoliko je efikasnost ojačavanja eksplozijom veća. Ojačavaju se čelični elementi konstrukcija, mašina i uređaja, ali se to odnosi i na druge materijale koji se nalaze u kontaktu sa agresivnom radnom sredinom, tamo gde su izuzetna udarna opterećenja, kao i klizni kontakti.

[8] Wilkins, M., Kusubov, A., Cline, C.: Dynamic Compaction of Aluminium Nitride Powder, Int. Conf. „Explomet - 85«, Portland, 1985.

[9] Nesterenko, V. F.: Vozmožnosti udarno-volnovjih metodov polučenija i kompaktirovanija bistozakalennih materialov, Fizika gorenia i vzriva, 1985, T.21, No 6, s. 85-98.

[10] Deribas, A. A., Staver, A. A.: Udarnoe sžatie smesi poroškov $\mathrm{TiO}_{2}+\mathrm{BaCos,} \mathrm{Fizika} \mathrm{gorenia}$ i vzriva, 1970, T.6, No 1 , s. 122-123.

[11] Deribas, A. A., Pai, V. V., Simonov, V. A.: Osobenosti soudarenija krupnogabaritnih plastin i nekotorie dopolniteljnije ogranicenlja oblasti i svarki, obrabotka metallov vzrivom, Marianske Lazni, 1976, T.1, s. 117-130.

[12] Deribas, A. A., Gavriljev, I. N., Zubkov, E. E., Kiseljev, A. N., Sobolenko, T. M., Teslenko, T. S.: Vzrivnoe uprocnenie nekotorih klassov stalei, Trudi II Sovešc. po obrabotki materialov vzrivom, Novosibirsk, 1982, 8. $78-85$. 